\title{
CEZA HUKUKUNDA DOĞRUDAN KAST
}

\author{
Arş. Gör. Hakan KARAKEHYA*
}

\section{ÖZET:}

TCK'da doğrudan kast; suçun kanuni tanımındaki unsurların bilerek ve istenerek gerçekleştirilmesi şeklinde düzenlenmiştir. Doğrudan kastın iki temel çeşidi bulunmaktadır: Birinci derecen doğrudan kast ve ikinci dereceden doğrudan kast. Amaçlama olarak da ifade ettiğimiz birinci dereceden doğrudan kastın öngörme ve isteme olmak üzere iki unsuru bulunmaktadır. Buna karşın bilme olarak ifade ettiğimiz ikinci dereceden doğrudan kast ise sadece zorunlu sonucun bilinmesinden ibarettir. Bu kast türünün varlığı açısından fail neticeyi istemese de istemiş gibi kabul edilir.

ANAHTAR KELİMELER: Kast, Doğrudan kast, Kusurluluk, Suçun manevi unsuru, Suç genel teorisi

\section{DIRECT INTENT IN CRIMINAL LAW}

\section{ABSTRACT}

Direct intent is defined in Turkish Criminal Code as; executing a crime knowingly and voluntary. There are two types of direct intent: Direct intent in the first degree and direct intent in second degree. Direct intent in the first degree named as purposing, has two basic elements as foreseeing and wanting. However direct intent in the second degree named also as knowing, insists of only being acquainted with distinct result. Regarding this type of intent, it is considered like that the result is wanted.

KEYWORDS: Criminal Intent, Direct Intent, Culpability, Men's Rea, General Criminal Theory

\section{GíRIŞ}

5237 sayılı Türk Ceza Kanunu, sistematik açıdan bakıldığında suçun manevi unsuru bakımından kast ve taksir olmak üzere iki tür kabul etmiş; bu iki türün her birini de kendi içerisinde ikiye ayırmıştır. Buna göre yeni kanunun öngördüğü manevi unsur türleri (doğrudan) kast, olası kast, bilinçli taksir ve

Anadolu Üniversitesi Hukuk Fakültesi Ceza ve Ceza Muhakemesi Hukuku Araştırma Görevlisi 
(basit) taksirdir. Bu manevi unsur türlerinden üçü, 765 sayılı kanunda da yer almaktaydı; ancak olası kast, söz konusu kanunda düzenlenmemişti. ${ }^{1}$

Kast, suçlu iradenin tipik şeklidir. Oldukça karışık bir kavram olması nedeniyle, kastın ele alınış, unsurlarının tespit ediliş ve incelenişi farklı şekillerde yapılabilmektedir. Bu bağlamda doktrinde de farklı tanımlamaların ve inceleme yöntemlerinin kullanıldığı görülmektedir. ${ }^{2}$

5237 sayılı kanunun, kastı kendi içerisinde doğrudan ve olası kast olarak ikiye ayırmak suretiyle düzenlemiş olması ve kasten işlenen suçlar bakımından, kastın türüne göre farklı cezalar öngörmesi nedeniyle, kastın türünün tespit edilmesi ve her bir kast türünün özelliklerinin net bir şekilde ortaya konulması, sadece teorik değil, artık pratik açıdan da büyük önem arzetmektedir.

Biz bu çalı̧̧mamızda, suç genel teorisinin önemli bir konusu olan doğrudan kast kavramı üzerine elimizden geldiği ölçüde ayrıntılı bir inceleme yapmaya gayret ettik. Bu bağlamda, öncelikle suçun manevi unsurunun tespiti, sonrasında doğrudan kast kavramının ortaya konulması ve türlerinin belirlenmesi, daha sonra doğrudan kastın olası kasttan farkının ortaya konulması ve son olarak da ulaştığımız neticelerin sistematik bir şekilde özetlenmesi çalışma planımızı oluşturmaktadır.

Çalışma yapılırken, doktrindeki farklı görüşlere yer verilmiş ve ülkemizde doğrudan kast üzerine bugüne kadar yapılan incelemelerden farklı olarak, amerikan ve alman hukuk doktrininde bazı yazarlarca kullanılan bir yöntem kullanılmıştır. $\mathrm{Bu}$ bağlamda doğrudan kast, birinci dereceden (amaçlama) ve ikinci dereceden (bilme) doğrudan kast şeklinde ikili bir ayrıma tabi tutulmak suretiyle incelenmiştir. Yazar tarafından, en azından konunun bu farklı değerlendirme yönteminin, literatüre katkı sağlayacağı umulmaktadır.

1765 sayılı kanunda suçun manevi unsuru bakımından uzunca bir süre sadece kast ve taksir şeklinde ikili bir ayrım yer almaktaydı. Ancak TCK'nın 45. maddesinde, 2003 yılında, 4785 sayılı kanunla yapılan değişiklik sonucu, bilinçli taksir düzenleme altına alınmış ve böylelikle bu manevi unsur türü de 765 sayılı kanun döneminde hukuk sistemimize dahil olmuştur.

2 EREM, Faruk-Ahmet DDANIŞMAN-Mehmet Emin ARTUK, Ceza Hukuku Genel Hükümler, Seçkin Yayınevi, Ankara 1997, s.443 


\section{SUÇUN MANEVİ UNSURU}

Doktrinimizde suçun manevi unsuru ve kusurluluk terimleri, çoğu kez aynı içeriği ifade eden kavramlar olarak kullanılmaktadırlar. ${ }^{3}$ Baskın görüşe göre, kusur yeteneğine sahip fail tarafından, fiilin kasten veya kanunun açıkça öngördüğü hallerde taksirle işlenmesi ve işlenen bu fiilde kusurluluğu kaldıran hallerden herhangi birinin bulunmamasi halinde manevi unsurun (ya da kusurluluğun) varlığı kabul edilmektedir. ${ }^{4}$ Yazarlardan bazıları kusurluluk için failde kusur yeteneğinin bulunmasını ön şart olarak kabul ederlerken ${ }^{5}$; bazıları da bu kavramı kusurluluğun ön şartı değil, bilakis faile ait bir özellik olarak kabul ederler. ${ }^{6}$

Alman doktrinindeki büyük çoğunluk ise kasten işlenen suçlar bakımından kastın tipiklik içinde manevi unsur olarak yer aldığı (subjektive Tatbestand); kusurluluğun (Schuld) ise kınanabilirliğe ilişkin olduğu kanaatindedirler. $\mathrm{Bu}$ çoğunluk görüşüne göre, taksirle işlenen suçlar, taksirin kendine özgü yapısı nedeniyle, kasten işlenen suçlardan bağımsız olarak ele alınmalıdır. ${ }^{7} \mathrm{Bu}$ nedenle Alman doktrinindeki genel eserlerde suçun unsurları

3 İki terimin aynı anlamda kullanılmasına ilişsin olarak bkz. İÇEL, Kayıhan. Ceza Hukukunda Taksirden Doğan Subjektif Sorumluluk, İstanbul Üniversitesi Yayınları, İstanbul 1967, s.7; EREM, Faruk. Ümanist Doktrin Açısından Türk Ceza Hukuku-I, Seçkin Yayınevi, Ankara 1995, s.487; HAKERİ, Hakan. Yeni Türk Ceza Hukukunun Temel Kavramları, Seçkin Yayınları, Ankara 2005, s.162; Bazı yazarlar ise manevi unsurun, isnat yeteneği ve kusurluluk olmak üzere iki alt kavramdan oluştuğunu kabul etmektedirler. Bkz. DÖNMEZER, Sulhi.-Sahir ERMAN, Nazari ve Tatbiki Ceza Hukuku II, Beta Yayınları, İstanbul 1999, s.143

4 ÖZBEK, Veli Özer. TCK İzmir Şerhi C.1, Seçkin Yayınları, Ankara 2005, s.247; CENTEL, Nur-Hamide ZAFER-Özlem Yenerer ÇAKMUT, Türk Ceza Hukukuna Giriş, Beta Yayınevi, İstanbul 2005, s.358 vd; ÖZTÜRK BahriMustafa Ruhan ERDEM- Veli Özer ÖZBEK, Uygulamalı Ceza Hukuku ve Emniyet Tedbirleri Hukuku, Seçkin Yayınevi, Ankara 1998, s.246 vd.

5 CENTEL-ZAFER-ÇAKMUT, s.358

6 TOROSLU, Nevzat. Ceza Hukuku Genel Kısım, Savaş Yayınevi, Ankara 2005, s.332;

7 Alman ceza hukuku genel kitaplarına bakıldığı zaman taksirle işlenen fiillerin, teşebbüs, ihmal ve iştirakin yanında kitapların ikinci bölümünde arka planda yer aldıkları görülecektir. Ön planda ise cezai fiillerin temel şekli olarak her zaman kasten işlenen fiiller bulunmaktadır. MITSCH, Wolfgang. "Fahrlässigkeit und Straftatsystem", Juristishe Schulung, Februar 2001, s.105; Bugün Alman hukukunda baskın olan görüşe göre taksir bir kusur çeşidi değil; cezalandırılabilen davranışların, "haksızlık ve kusurluluğa ilişkin elementleri 
incelenirken, ekseriyetle, kasten işlenen suçlar ve taksirle işlenen suçlar bakımından incelemenin ayrı ayrı yapıldığı görülmektedir. ${ }^{8}$ Ancak hem kast hem de taksiri suçun tipikliği içinde manevi unsur olarak inceleyenler de bulunmaktadır. ${ }^{9}$ Bunun yanında yine azınlık olmakla birlikte hala kast ve taksiri kusurluluk içinde inceleyenler de vardır. ${ }^{10}$

Kanaatimizce de suçun manevi unsuru, fail ile fiil arasındaki psişik bağı ve bunun derecesini gösteren kalıpları ifade etmekte, bu bakımdan da kınanabilirliğe ilişkin bir kavram olan kusurluluktan farklı bir anlam içermektedir. ${ }^{11}$ Çünkü fail ile fiil arasındaki psişik bağ ile fiilin kınanabilirliği birbiriyle yakından ilişkili, ancak farklı hususlardır. ${ }^{12}$

\section{DOĞRUDAN KAST KAVRAMI (DOLUS DIRECTUS; Direkter VORSATZ)}

Kast kusurun tipik şeklidir ve kural olarak suçlar, ancak kasten işlendikleri takdirde cezalandırılırlar. Bu bağlamda suç tiplerinde suçun kasten işleneceğinin ayrıca belirtilmesine gerek yoktur. ${ }^{13}$ Kast, yeni TCK'nın 21. maddesinde kendi içerisinde ikili bir ayrıma tabi tutularak düzenlenmiş ve önceki kanundan farklı olarak, bu maddede açık tanımlamalara yer verilmiştir. $\mathrm{Bu}$ bağlamda kast başlığı altında, öncelikle doğrudan kast, daha sonra ise olası kast tanımlanmıştır. Ancak kanunda, doğrudan kastı ifade etmek için doğrudan ibaresi kullanılmaksızın sadece kast adı altında bir tanımlama yapılmıştır.

bünyesinde barındıran, özel bir tipi"dir. WESSELS, Johannes-Werner BEULKE, Strafrecht Algemeiner Teil, Heidelberg 2003, s. 232.

8 Bu konuda örnek için bkz. WESSELS-BEULKE, s. 103 vd-393 vd.; GROPP, Walter. Strafrecht Algemeiner Teil, Springer, Berlin, Heidelberg... 1998, s. 95 vd-381 vd; JESCHECK, Hans-Heinrich-Thomas WEIGEND, Lehrbuch des Strafrechts Algemeiner Teil, Dunker\&Humblot, Berlin,1996, s.232 vd.-s.561 vd.

9 Örnek olarak bkz. KINDHAESER, Urs. Strafrecht Algemeiner Teil, BadenBaden 2002, s.151 vd.

10 Bkz. BAUMANN, Jürgen-Ulrich WEBER- Wolfgang MITSCH, Strafrecht Algemeiner Teil, Verlag Ernst und Werner Gieseking, Bielefeld 2003, s.444 vd.

115237 sayılı TCK'nın da bu düşünce doğrultusunda kaleme alınışı konusunda bkz. ÖZGENÇ, İzzet. Türk Ceza Kanunu, Gazi Şerhi (Genel Hükümler), Seçkin Yayınevi, Ankara 2005, s.241 vd.

12 KARAKEHYA, Hakan. "Olası Kast”, Ceza Hukuku Dergisi, S.2, Seçkin Yayınevi, Ankara 2006, s.21

13 HAKERİ, s. $180 \mathrm{vd}$. 
Kanuni ifadeye göre kast; suçun kanuni tanımındaki unsurların bilerek ve istenerek gerçekleştirilmesidir. Bu tanımlama kanun açıkça belirtmese de, doğrudan kastı ifade etmektedir ${ }^{14}$ ve tanımlamadan anlaşıldığı üzere bu manevi unsur türünün iki temel unsuru bulunmaktadır: Bilme ve İsteme. Doktrinde de doğrudan kast incelenirken, bu kavramın hep bu iki unsur üzerinden ele alındığ 1 görülmektedir. ${ }^{15} \mathrm{Bu}$ bağlamda bir fiilin kasten işlendiğinin kabul edilebilmesi için fiilin hem bilinmesi hem de istenmesi zorunludur. Bu iki unsurdan birisinin eksik olduğu hallerde ise doğrudan kastın varlığından söz etmek mümkün olamayacaktır.

Kastı açıklayan kuramlar üç ana başlık altında toplanabilmektedir. Bunlar, kastın varlığı için neticenin tasavvur edilmiş olmasını yeterli gören tasavvur kuramı, iradenin varlığını yeterli gören irade kuramı ve hem tasavvurun hem de iradenin varlığını zorunlu kabul eden bilinç ve irade kuramıdır. ${ }^{16}$ Günümüzde ağırlıklı kabul edilen kuram, karma görüşü yansıtan bilinç ve irade kuramıdır. Bu bağlamda TCK'nın 21. maddesinde kast tanımı yapılırken, "bilerek ve istenerek" denilmek suretiyle, kastın varlığı için hem tasavvur hem de iradenin varlığı aramış, dolayısıyla bilinç ve irade kuramı kabul edilmiştir.

Ancak isteme bakımından bir sorun olmamakla birlikte, bilme unsuru bakımından doğrudan kasta ilişkin bir takım terimsel sorunlar olduğu kanaatindeyiz. Nitekim bilme, kelime anlamı olarak bir kesinlik ifade etmektedir. Bu bağlamda neticenin gerçekleşeceğinin kesin olması ve failin bunu tasavvur etmesi halinde ancak bilmeden söz edilebilecektir. Buna karşın doğrudan kastın söz konusu olduğu her halde, netice bakımından bir kesinliğin bulunması gerekli değildir. Dolayısıyla ihtimal dahilinde olan, bir başka deyişle

$14 \mathrm{Bu}$ noktada manevi unsur türlerini ifade etmek için kanunda kullanılan terminolojiye ilişkin olarak şunu ifade etmek isteriz ki; 5237 sayılı kanunda kast başlığı altında kast ve olası kast, taksir başlığı altında ise taksir ve bilinçli taksir düzenlenmiştir. Ancak genel bir problem olarak, kanunda ya da hukuk metinlerinde kast terimi kullanıldığı zaman her iki kast türünün mü yoksa bunlardan olası kast haricindeki (doğrudan) kastın mı ifade edildiği açık bir şekilde anlaşılamamaktadır. Çünkü kanun koyucu doğrudan kastı ifade etmek için doğrudan ibaresini kullanmamıştır. Aynı sorun taksir terimi bakımından da geçerlidir. Bu nedenle biz karışıklığa neden olmaması için çalışma içerisinde, olası kast haricindeki kastı ifade etmek için doğrudan kast, bilinçli taksir haricindeki taksiri ifade etmek içinde de basit taksir terimlerini kullanacağız.

15 Bkz. TOROSLU, s.181 vd.; GROPP, s.141 vd.; ÖNDER, Ayhan. Ceza Hukuku Genel Hükümler II-III, Beta Yayınevi, İstanbul 1992, s.308

16 Kuramlar konusunda ayrıntılı bilgi için bkz. EREM-DANIŞMAN-ARTUK, s.443 vd. 
öngörülen (bilinen değil) neticenin istenmesi halinde de doğrudan kast söz konusu olabilmektedir. Bu nedenle kastın unsurlarını bilme ve isteme yerine öngörme ve isteme olarak tespit etmek daha yerinde olacaktır kanaatindeyiz. ${ }^{17}$

Bilmenin öngörmeden daha kesin bir anlam ifade etmesi nedeniyle, söz konusu unsur bilme olarak kabul edildiği zaman, mantıksal olarak öngörmeyi kapsamayan bir sonuca ulaşmak mümkün olacaktır. Dolayısıyla öngörmenin söz konusu olduğu hallerde sanki kasttın varlığı kabul edilemeyecekmiş gibi bir anlam çıkartılması mümkündür. Buna karşın öngörmenin unsur olarak kabul edilmesi halinde, bilmenin varlığına bağlı olarak da doğrudan kastın vücut bulduğunun kabul edileceği genel bir mantık kuralıdır. Çünkü öngörme, bilmeden, zihinsel kesinlik bakımından daha dar kapsamlı bir kavramdır. Yorumda kullanılan en önemli mantık kurallarından evleviyet (öncelikArgumentum a fortiori) ilkesi gereği azın kabul edildiği yerde daha fazlasının yeterli görülmemesi söz konusu olamayacağından, öngörmenin kastın kabulü için yeterli olduğu hallerde, bilmenin söz konusu olması halinde, evleviyetle (öncelikli olarak) kastın varlığı kabul edilebilecektir. ${ }^{18}$ Biz bu nedenle aşağıda birinci dereceden doğrudan kastı incelerken unsurları öngörme ve isteme olarak ele almayı daha uygun gördük.

Alman Ceza Kanunu'nun (Strafgesetzbuch-StGB) genel hükümlerinde manevi unsur türlerine ilişkin net bir düzenleme bulunmamaktadır. ${ }^{19}$ StGB'nin 15. maddesinde "Kasıtlı ve Taksirli Hareket" başlığı altında, kanunda taksirli hareketin cezalandırılmadığı hallerde sadece kasitlı hareketlerin cezalandırılabileceği düzenlenmiş, manevi unsur türlerine ilişkin bir tanım ise verilmemiştir. $^{20}$

Alman doktrininin önde gelen yazarlarından Roxin, doğrudan kastı, bizim de kabul ettiğimiz üzere ikiye ayırmaktadır: Birinci dereceden doğrudan kast (Absicht, dolus directus ersten grades) ve ikinci dereceden doğrudan kast

17 Doktrinde kastın bilme unsuru incelenirken bu konunun öngörmeyi de kapsar şekilde ele alındığı; bunun bazı eserlerde açıkça ifade edildiği, bazı eserlerde ise bilme yerine ara ra öngörme terimin kullanılması suretiyle vurgulandığ 1 görülmektedir. Bkz. HAKERİ, 182; GROPP, s.142; DÖNMEZER-ERMAN, s.216; ÖZBEK, s.249

18 KARAKEHYA, s.38 vd; Yorumda kullanılan temel mantık kurallarından birisi olan evleviyet ilkesi hakkında ayrıntılı bilgi için bkz. GÖZLER, Kemal. Hukukun Genel Teorisine Giriş, US-A yayıncllık, Ankara 1998, s.178 vd.

20 Alman Ceza Kanunu maddelerinin 1994 yılı itibarıly son halinin Türkçe çevirileri için bkz. İÇEL, Kayıhan-Feridun YENISEY, Karşılaştırmalı ve Uygulamalı Ceza Kanunları, Beta Yayınları, İstanbul 1994, s.929 vd. 
(der direkte Vorsatz; dolus direktus zweiten grades). Buna göre; eğer fail belirli bir amaca yönelik olarak bir davranış1 ${ }^{21}$ gerçekleştiriyorsa, bu durumda birinci dereceden doğrudan kast; failin belirli bir amaca yönelik olarak gerçekleştirdiği davranışa bağlı olarak, gerçekleşmesi zorunlu bir netice söz konusuysa, bu ikinci netice bakımından ikinci dereceden doğrudan kast söz konusu olacaktır. ${ }^{22}$

Anglo-sakson hukukunun bir parçası olan Amerika Birleşik Devletleri hukuk sisteminde ise, kast ve taksir gibi manevi unsur kalıplarının kusurluluk içinde değerlendirildiği görülmektedir. Ülkedeki eyaletlerin yaklaşık $2 / 3$ 'ünün çok büyük oranda etkilenerek ceza kanunlarını benimsediği bir tasarı olan 1962 tarihli Model Penal Code'nin ${ }^{23}$ 2. maddesinin 2. bölümünde kusurluluğun genel şartları düzenlenmiştir. $\mathrm{Bu}$ bölümün 2. paragrafinda ise kusur çeşitleri ele alınmıştır. Burada yer verilen kusur çeşitleri dört tanedir. Söz konusu düzenlemeye göre, bir kişinin işlediği fiilden sorumlu tutulabilmesi için (section 2.05 'teki istisna hariç) bir fiili şu kalıplardan birisine uygun olarak işlemesi gerekir: purposely (amaçlayarak), knowingly (bilerek), recklessly (umursamazlık yaparak) veya negligently ( taksirli davranarak). ${ }^{24} \mathrm{Bu}$ ayrımdan da anlaşılacağı üzere Model Penal Code de doğrudan kastı, amaçlama (to purpose) ve bilme (knowing) olarak ikiye ayırmak suretiyle düzenlemiştir.

21 Hem hareketi hem de ihmali ifade etmesi bakımından burada "davranış" terimini kullanmayı uygun bulmaktayız. İhmal doğası gereği hareketin antitezini oluşturur. Ancak bu da insanın dışa yansıyan bir davranışı, diğer bir ifade ile süjenin kişiliğinin bir açığa çıkış biçimidir. TOROSLU, s.113

22 ROXIN, Claus. Strafrecht Algemeiner Teil-I, C.H.Beck, München 1997, s.364; aynı yönde ayrımlar için bkz. GROPP, s.141; WESSELS-BEULKE, s.77

23 Amerikan Barolar Birliği tarafından finanse edilen ve ticari amaç gütmeyen bir kuruluş olan Amerikan Hukuk Enstitüsü ( The American Law Instıtute) tarafindan, model bir ceza kanunu tasarısı (Model Penal Code) oluşturulmuştur. Bir grup hakim, hukukçu ve uzman tarafindan, Amerika Birleşik Devletleri'ndeki ceza hukukunu genel olarak belirlemek amaciyla 1952 yılında bu tasarıya ilişkin çalışmalara başlamış ve 13 öneri taslağından sonra 1962 yılında tasarı tamamlanmıştır. 1962 yllından itibaren, ABD eyaletlerinin yaklaşı 2/3'ü Model Penal Code'den etkilenerek ceza kanunlarını benimsemişlerdir. WALLACE, Harvey-Cliff ROBERSON, Principles of Criminal Law, Longman Publishers, New York 1996, s.13

24 DRESSLER, Joshua. Cases and Materials on Criminal Law, Thomson West, St Paul MN. 2003, s.154 vd. 


\section{DOĞRUDAN KAST ÇEȘITLERİ}

\subsection{Genel Olarak}

Doğrudan kastın iki temel çeşidi bulunmaktadır: Birinci derecen doğrudan kast ve ikinci dereceden doğrudan kast. Amaçlama olarak da ifade ettiğimiz birinci dereceden doğrudan kastın öngörme ve isteme olmak üzere iki unsuru bulunmaktadır. Bu iki unsur aşağıda ayrıntılı olarak incelenmiştir. Buna karşın bilme olarak ifade ettiğimiz ikinci dereceden doğrudan kast ise sadece zorunlu sonucun bilinmesinden ibarettir. Bu kast türünün varlığı açısından sonuç irade edilmese bile istenmiş gibi kabul edilir. ${ }^{25}$ Zaten iradenin (istemenin) varlığ 1 halinde birinci dereceden doğrudan kast söz konusu olacaktır. Failin zorunlu sonucu biliyor olması ikinci dereceden doğrudan kastın varlığının kabulü için yeterlidir. ${ }^{26}$ Aşağıda ikinci dereceden doğrudan kast türünün unsurlarını incelerken, temel olarak bilmeden ne anlaşılması gerektiği ve bilmenin şartları ele alınacaktır.

Kanunumuz doğrudan kastın çeşitleri arasında ceza miktarı bakımından bir ayrım yapmamıştır. Hatta kanundaki ifadeye bakıldığında doğrudan kastın çeşitlerinin de kanun içerisinde açıkça belirtilmediği görülmektedir. Ancak yargı içtihatları ve doktrindeki görüşler 1şığında bu tür bir ayrımı ortaya koymak, doğrudan kastın içeriğini daha iyi anlayabilmek bakımından faydalı olacaktır kanaatindeyiz. Her ne kadar bizim kanunumuzda bu ayrıma açıkça yer verilmemiş olsa da, yukarıda da belirttiğimiz üzere Model Penal Code'de doğrudan kastın her iki çeşidi de (amaçlayarak-purposely ve bilerek-knowingly olmak üzere) ayrı ayrı düzenleme altına alınmış ve tanımlanmıştır. ${ }^{27}$

\subsection{Birinci Dereceden Doğrudan Kast (Amaçlama)}

\subsubsection{Genel Olarak}

Birinci dereceden doğrudan kastla işlenen suçlarda fail, neticeyi amaçlayarak davranışını gerçekleştirmektedir. Bir başka deyişle meydana gelecek netice failin davranışı gerçekleştirmesindeki asıl amaçtır. Fail neticeyi istemekte ve o neticeyi oluşturacak uygun bir davranış yapmak suretiyle fiili oluşturmaya çalışmaktadır. Bu bağlamda fail, davranışına bağlı olarak meydana

25 WESSELS-BEULKE, s.79

26 ROXIN, s.364

27 DRESSLER, 154 vd. Model Penal Code'nin tam metnine de aynı eserin sonundaki ek kısmından ulaşılabilir. 
gelecek neticeyi en azından öngörmekte ve bu neticeyi istemektedir. Neticeyi öngörme ve isteme, birlikte amaçlama olarak da ifade edilebilir kanaatindeyiz. ${ }^{28}$

Şunu da belirtmek gerekir ki; amaçlama terimini yukarıda da bahsettiğimiz üzere sadece neticeyi öngörme ve isteme bakımından kullanıyoruz. Bu bağlamda söz konusu terimin, failin fiili gerçekleştirirken (veya gerçekleştirmeye teşebbüs ederken) hangi dürtülerle veya motivasyonla hareket ettiğine ilişkin bir içeriği yoktur. Saik olarak adlandırdığımız bu tür motivasyonlar, sadece kanun koyucunun suçun gerçekleşmesi bakımından failin saikini de dikkate aldığı suç tipleri bakımından önem arzeder. ${ }^{29}$ Onun dışındaki hallerde ise failin fiili amaçlarken hangi motivasyonla hareket ettiğginin bir önemi bulunmamaktadır.

\subsubsection{Birinci Dereceden Doğrudan Kastın Unsurları}

\subsubsection{1. Öngörme}

Yukarıda da belirttiğimiz üzere bu unsur kanunda ve doktrinin genelinde bilme adı altında incelenmektedir. Ancak bu unsurun bilme olarak ifade edilmesi halinde öngörmenin kast kapsamında değerlendirilemeyeceği; ancak söz konusu unsurun öngörme olarak ifade edilmesi halinde, bilmenin evleviyetle kast kapsamında değerlendirileceği düşüncesiyle biz öngörme terimini kullanmayı uygun buluyoruz.

Öngörme, failin davranışına bağlı olarak neticenin gerçekleşme ihtimalini tasavvur etmesidir. ${ }^{30} \mathrm{Bu}$ ihtimalin çok büyük ya da çok küçük olmasının bir önemi yoktur. ${ }^{31}$ Bu bağlamda örneğin, çok kötü nişancı olan birisi 100 metre uzağındaki kişiye ateş ettiği zaman, \%1 ihtimal de olsa onun ölümüne

28 Alman doktrininde de birinci dereceden doğrudan kastı ifade etmek için doktrinde amaçlama (Absicht) teriminin kullanıldığı görülmektedir. bkz. GROPP, s.147; WESSELS-BEULKE, s.77; ROXIN, s.364

29 Örneğin hırsızlık fiili bakımından kanun koyucu failin saikine önem vermiş ve suçun gerçekleşmesi için failin faydalanmak saikiyle hareket etmesini aramışır. Eğer bu saik failde yoksa hırsızlık suçu oluşmayacaktır. Kanunun suçun oluşumu bakımından failin saikine de önem verdiği hallerde "özel kast" söz konusu olur. ÖZBEK, s. 255

30 DÖNMEZER-ERMAN, s.216

31 Gropp'a göre, öngörmenin (bilmenin) kabulü için hayatın normal akışında fiilin oluşunun önceden öngörülebilir olması ve fiil bakımından da herhangi bir hukuka uygunluk nedeninin bulunmaması gerekir. GROPP, s.142 
neden olabileceğini tasavvur edebiliyorsa, bu bilince sahip olması birinci dereceden doğrudan kastın öngörme unsurunun gerçekleşmesi bakımından yeterlidir. Buna karşın fail, bomba koyduğu arabada bulunan kişinin, bombayı patlattı̆̆ zaman öleceğini bilmektedir. Burada artık öngörmeden değil, bilmeden söz edilir. Çünkü davranışa bağlı olarak sonucun meydana gelmesi muhtemel değil; mutlak veya mutlaka yakındır. Bilme, öngörmeye oranla daha kuvvetli bir tasavvur derecesi olduğundan, birinci dereceden doğrudan kast bakımından ilk unsurun oluşmasına evleviyetle yeterlidir.

Öngörmenin kapsamına kural olarak, maddi hukuk açısından cezayı ağırlaştıran tüm hususlar girmektedir. Eğer maddi hukuk bakımından suçun oluşumuna etkili veya cezayı ağırlaştıran nedenin failce öngörülmesi söz konusu değilse; fail bu durumdan faydalanır. Dolayısıyla öngörülmeyen netice, suçun oluşumuna ilişkinse suç oluşmamış sayılır; cezayı arttırmaya ilişkin ise de ağırlaştırırcı neden faile uygulanmaz. Ancak netice sebebiyle ağırlaşmış bir suç söz konusu ise, bu durumda kanunun açık hükmüne dayalı olarak failin, ağırlaşmış neticeyi öngörüp öngörmemesinin bir önemi yoktur. ${ }^{32}$ Eğer bu ağırlaşan netice bakımından failin en azından basit taksiri bulunuyorsa, bu durum failin ağırlaşan neticeden sorumlu tutulabilmesi için yeterlidir. ${ }^{33}$

Suçların nitelikli halleri bakımından belirtilmesi gereken bir husus da şudur ki; eğer nitelikli hal failin cezasının arttırılmasına değil; bilakis azaltılmasına ilişkinse, bu durumda failin cezayı azaltan nedeni bilip bilmemesinin bir önemi yoktur. Her halükarda indirimden yararlanacaktır. Ancak yukarıda da belirttiğimiz üzere, nitelikli hal cezanın ağırlaştırılması sonucunu doğuruyorsa, cezanın arttırılabilmesi için bunun muhakkak fail tarafindan öngörülüyor olması gereklidir. ${ }^{34}$

\subsubsection{2. İsteme}

İsteme failin neticeye ilişkin iradesini ifade eden unsurdur. Eğer fail öngördüğü veya bildiği neticenin gerçekleşmesini irade ediyorsa; bu durumda kastın ikinci unsuru olan isteme gerçekleşmiş olacaktır. Doktrindeki bazı

\section{DÖNMEZER-ERMAN, s.218}

33 Netice sebebiyle ağırlaşan suçlardaki neticenin de muhakkak öngörme içerisinde yer alması gerekli değildir. Önemli olan neticeyi öngörmesinin failden beklenip beklenemeyeceğidir. Nitekim basit taksir bakımından öngörme gerekli bir unsur değildir ve TCK'nın 23. maddesi dikkate alındığında, ağırlaşan netice bakımından basit taksir derecesinde bir sorumluluk bile faile ağırlaşan neticeden kaynaklanan cezanın uygulanması için yeterlidir.

34 ÖNDER, s.308; HAKERİ, s.183 
eserlere bakıldığında, kastın unsuru olarak istemenin bilmeden (öngörmeden) önce ele alındığı görülmektedir. ${ }^{35}$ Çünkü böyle bir inceleme tarzı konuyu açıklamak bakımından kolaylık sağlamaktadır. Şöyle ki; suç yolunda fail, ilk önce neticeyi istemekte daha sonra o neticeyi gerçekleştirmeye yönelik bir davranışla amacına ulaşmaya çalışmaktadır. Bu itibarla suç yolunda kastın tamam olan ilk unsuru iradi unsurdur. İradi unsur tamamlandıktan sonra failde zihinsel unsur devreye girer ve istenen neticeye uygun davranış gerçekleştirilir. ${ }^{36}$ Dolayıyla doğrudan kastta, iradi unsurun zihinsel unsura, bir başka deyişle istemenin öngörmeye göre daha ön planda ve baskın olduğunu söylemek yanlış olmayacaktır. ${ }^{37}$

Kastın isteme unsurunun gerçekleştiği hallerde, zihinsel açıdan failin neticeyi öngörmesinin veya bilmesinin herhangi bir önemi yoktur. Her ikisinde de fail birinci dereceden doğrudan kasttan sorumlu olacaktır. Ancak isteme unsurunun gerçekleşmediği hallerde bu iki tasavvur derecesinden hangisinin gerçekleştiği büyük önem arzeder. Eğer fail neticeyi istemiyor ama biliyorsa, bir başka deyişle gerçekleştirdiği davranışa bağlı olarak neticenin meydana gelmesi muhakkak veya muhakkaka yakınsa bu durumda fail ikinci dereceden doğrudan kasttan sorumlu olur. ${ }^{38} \mathrm{Bu}$ durumda fail neticeyi istemese bile istemiş gibi kabul olunur. Ancak failin davranışına bağlı olarak neticenin meydana gelmesi ihtimal dahilindeyse, bir başka deyişle netice, davranışın zorunlu sonucu değilse; bu durumda fail sadece olası kast veya bilinçli taksirden sorumlu tutulabilecektir. ${ }^{39}$ Çünkü istemenin söz konusu olmadığı hallerde doğrudan kast sorumluluğunun ortaya çıkması, ancak neticenin zorunlu sonuç olması halinde ve ikinci dereceden doğrudan kast şeklinde olabilecektir.

35 Örnek olarak bkz. ÖNDER, s.263 vd.; TOROSLU, s. 185

36 Kasten işlenen suçlarda suç yolu ve düşünce aşaması için bkz. TOROSLU, s. 248

37 "Bilme unsuru isteme unsurundan önce gelmekte ise de, kasta özelliğini veren unsurun isteme olduğu kuşkusuzdur.” TOROSLU, s.181

38 GROPP, s.149

39 Roxin, bu tür hallerde öngörülen neticeden sorumluluğun olası kast mı yoksa bilinçli taksir kapsamında değerlendirileceğinin tespiti açısından iki tür arasındaki farkı şu şekilde ortaya koymaktadır:

Gerçekleşmesi mümkün olan bir tipik fiili göz önünde bulunduran (öngören) bir kimse, buna rağmen kendisini planından vazgeçirmezse, tipik fiille korunan hukuki menfaate karşı bir karar verdiğinin bilincindedir. Bu hukuki menfaate karşı verilen karar, olası kastı bilinçli taksirden ayıran özelliktir. ROXIN, s.373 


\section{3. İkinci Dereceden Doğrudan Kast (Bilme)}

\subsubsection{Genel Olarak}

İkinci dereceden doğrudan kastın söz konusu olduğu hallerde fail davranışına bağlı olarak meydana gelecek neticeyi amaçlamamaktadır. ${ }^{40}$ Ancak neticenin meydana gelmesi davranışının zorunlu sonucudur. Bu durumda fail neticeyi istemese de istemiş gibi kabul olunur ve ikinci dereceden doğrudan kast sorumluluğu doğar. ${ }^{41}$ Dolayısıyla bu doğrudan kast türünün gerçekleşebilmesi için failin, davranışa bağlı zorunlu neticeyi istememesi ama bilmesi gerekir. Eğer zorunlu sonucu isterse, zaten birinci dereceden doğrudan kast sorumluluğu doğacaktır.

$\mathrm{Bu}$ anlatılanlardan da anlaşılacağı üzere ikinci dereceden doğrudan kast, daima failin amaçladığı hukuki öneme sahip olsun veya olmasın istenilen asıl amaç dışında, davranışa bağlı olarak ortaya çıkacak, zorunlu bir ikincil neticeye ilişkindir. Çünkü failin amaçladığı (ve dolayısıyla istediği) neticelere ilişkin olarak ortaya çıkacak kast, her zaman için birinci dereceden doğrudan kast kapsamında değerlendirilecektir. ${ }^{42}$

Birkaç örnekle konuyu netleştirmek ve ikinci derecen doğrudan kastı birinci dereceden doğrudan kasttan ayırmak gerekirse şu örnekler verilebilir: Failin öldürmek istediği kişinin içinde bulunduğu uçağı düşürmesi halinde, asıl öldürmek istediği kişi bakımından birinci dereceden doğrudan kastı söz konusudur. Çünkü fail bildiği bu neticeyi aynı zamanda da istemektedir. Buna karşın fail uçaktaki diğer yolcuların ölmesi konusunda bir isteğe sahip değildir, ancak asıl gerçekleştirmek istediği amaca bağlı olarak davranışını gerçekleştirdiğinde, uçaktaki diğer yolcuların da muhakkak olarak (zorunlu sonuç olarak) öleceğini bilmektedir. İşte bu durumda failin diğer yolcuların ölümü bakımından da ikinci dereceden doğrudan kastı söz konusudur. Burada gerek asıl amaçlanan neticeye bağlı olarak oluşacak gerekse bu fiilin yanında meydana gelecek ikincil neticeye bağlı olarak oluşacak fiillerin her ikisi de, ceza normu tarafından yasaklanmış fiillerdir. Bununla birlikte karadan oldukça uzakta, 1ssız bir yerde eğlenmek amacıyla gemisini batıran alkollü gemi sahibinin, kendisiyle birlikte gemide bulunan ve kendisinin aksine yüzme bilmeyen arkadaşının ölümü bakımından da ikinci dereceden doğrudan kastı söz konusudur. Nitekim failin burada arkadaşını öldürmek gibi amacı yoktur. Zaten

40 GROPP, s.149

41 ÖNDER, s.264; WESSELS-BEULKE, s.213

42 Neticenin davranışın zorunlu sonucu olmasının söz konusu olduğu hallerde doğrudan kast söz konusu olur. ROXIN, s.371 vd. 
ası1 amacının arkadaşını öldürmek olduğunun ortaya konulması halinde, failin birinci dereceden doğrudan kastı söz konusu olacaktır. Ancak her ne kadar arkadaşını öldürmek amaciyla hareket etmese de, amaçladığı fiile bağlı olarak arkadaşının öleceğinin de bilincindedir. Burada yukarıdaki örnekten farklı olarak sadece ikincil zorunlu neticeye ilişkin fiil ceza normu tarafindan yasaklanmıştır. Buna karşın asıl amaçlanan neticeye ilişkin fiilin ceza normuna veya başkaca bir hukuk kuralına aykırılığı söz konusu değildir. Çünkü kişinin kendi malına zarar vermesi, kural olarak hukuka uygun bir davranıştır.

Biz failin zorunlu ikincil neticeyi tasavvur etmesini ifade etmek için bilme terimini kullanmayı uygun buluyoruz. ${ }^{43}$ Nitekim bilme neticenin meydana gelmesi bakımından bir muhakkaklığı ifade etmektedir. İkinci dereceden doğrudan kastın tek temel unsuru da zorunlu neticeye ilişkin bu bilmenin gerçekleşmiş olmasıdır.

Bununla birlikte bizim de kabul ettiğimiz üzere hukuk doktrininde, zorunlu sonucu bilme, ikinci dereceden doğrudan kast adı altında, bir doğrudan kast türü olarak kabul edilmesine rağmen; bunun kanundaki tanımlamayla bire bir uyuşmadığı da aşikardır. Nitekim kanun koyucu, karma teoriyi kabul ederek, kanun metninde "bilerek ve isteyerek" demek suretiyle, doğrudan kast bakımından bilme ve istemenin her ikisinin de birlikte olmasını zorunlu kabul etmiştir. Her ne kadar doktrinde eğer netice davranışın zorunlu sonucuysa fail bunu istemiş gibi kabul edilmelidir denilmekteyse de, bu husus son derece eleştiriye açıktır. Çünkü bir çok olayda, fail çok istediği birinci neticeye bağ 1 olarak hiç istemediği zorunlu ikinci neticelerin meydana gelmesini de kabul edebilmektedir. $\mathrm{Bu}$ zorunlu neticeleri, failin her durumda istediğini söylemek, bazı yazarlarca isteme kavramının içeriğine ve dolayısıyla pozitif metne uygun görülmeyebilecektir. Nitekim isteme, çoğu kez meydana gelen neticeden memnun kalmayı en azından hoşnut olmayı gerektirir. Ancak örneğin çok öldürmeyi istediği hasmını öldürmek için büyük uğraşlar veren bir kimse, sonunda zor da olsa hasmının aracına bomba koymayı başardığında, arabaya hasmıyla birlikte binen tanımadığı bir kimsenin ölmesini amaçlamamaktadır. Ancak bir daha hasmını öldürmek için uygun firsat bulamayacağını düşünen fail, arabayı havaya uçurduğunda hasmıyla birlikte ölen tanımadığı kişinin ölümünden hiç de hoşnut değildir ve bu sonucu istememektedir. Buna rağmen asıl amacına ulaşmak için o zorunlu sonucun meydana gelmesini de kabul etmiştir. Bu bağlamda madem sonuç zorunludur; o zaman fail bunu istemiş kabul edilmelidir demek, son derece kestirme ve kanun metnine uygun olmayan

43 Gropp bu durumu "kesin bilmeye rağmen davranışta bulunma" (Handeln trotz sicheren Wissens) olarak ifade etmektedir. GROPP, s.149; Yine Model Penal Code de bu durumu "bilme" (knowing) olarak ifade etmektedir. bkz. yukarıda 3.1. no'lu başlik. 
bir kabul ediş olarak eleştirilebilecektir. Bu nedenle kanaatimizce Model Penal Code'de olduğu gibi, kanun koyucunun amaçlama ve bilmeyi ayrı ayrı hüküm altına alması daha yerinde olacaktır.

Bununla birlikte biz, hukuk doktrinde baskın olan görüş doğrultusunda, zorunlu sonucu failin istemiş olduğu şeklindeki kabule bağlı olarak çalışmamızı gerçekleştireceğiz. Ancak burada eleştiriye açık olan bu hususu da vurgulamayı uygun buluyoruz. Aşağıda ikinci dereceden doğrudan kastın oluşumu bakımından bilmenin ne şekilde olması gerektiği alt başlıklar halinde incelenecektir.

\subsection{2. İkinci Dereceden Doğrudan Kastın Unsurları}

\subsubsection{Herhangi Bir Amaca Yönelik Bir Davranışın Yapılmış} Olmas1

İkinci dereceden doğrudan kastta fail, öncelikli olarak meydana geleceğini bildiği ikincil neticeye yönelik olmayan bir davranışta bulunur. Yukarıda da belirttiğimiz üzere, davranışın asıl nedenini oluşturan neticenin hukuka aykırı olup olmamasının bir önemi bulunmamaktadır. Örneğin, sigorta parası almak için 1ssız, açık denizde gemisini batıran kişinin fiili, bu duruma örnek olarak verilebilir. Bu örnek bakımından failin amaçladığ 1 fiil hukuka aykırıdır. Çünkü sigortadan para olmak üzere gemiyi kasten batırmak hukuk düzeninin yasakladığı bir davranıştır. Burada failin amacı gemiyi batırmak, saiki ise sigortadan para almaktır. ${ }^{44}$ Ancak failin, sırf zevk için, eğlenmek amacıyla gemisini batırdığı durumda ise, kendi malına zarar verme amaciyla hareket etmesine bağlı olarak herhangi bir hukuka aykırılık söz konusu olmayacaktır.

3.3.2.2. Davranışa Bağlı Olarak Ceza Normu Tarafindan Sonuç Bağlanmış Asıl Amaç Dışında İkincil Bir Neticenin Oluşmasının Zorunlu Olması

İkinci dereceden doğrudan kast bakımından gerekli diğer bir husus ise, failin davranışına bağlı olarak, asıl amaçlanan netice dışında, meydana gelmesi zorunlu ve muhakkak bir neticenin daha olmasıdır. ${ }^{45}$ Yukarıdaki örnek üzerinden devam edersek, gemisini batıran failin yanında, kendisinin aksine yüzme bilmeyen bir de arkadaşının olduğunu kabul edelim. Fail, asıl amacı olan fiili gerçekleştirdiği, yani gemiyi batırdığı zaman, gemide bulunan ve kendisinin

44 Amaç ve saik konusunda ayrıntılı bilgi ve bu iki kavramın birbirinden farkının tespiti için bkz. DÖNMEZER-ERMAN, s.224

45 WESSELS-BEULKE, s.79; ÖNDER, s.264 
aksine yüzme bilmeyen arkadaşının ölmesi amaçlanan fiile bağlı olarak ortaya çıkacak zorunlu sonuçtur. ${ }^{46} \mathrm{Bu}$ durumu kurallaştırarak ifade edersek, davranışın gerçekleştirilmesiyle amaçlanan neticenin meydana gelmesi halinde, ona bağlı olarak ceza normu tarafindan yasaklanmış zorunlu bir başka netice daha meydana gelecektir. Aynı şekilde alkollü olan failin eğlenmek amacıyla gemiyi batırması halinde de, asıl amaç olan gemiyi batırma, yukarıdaki örnekte olduğunun aksine hukuka uygun bir fiil olsa da, ikincil zorunlu netice olarak meydana gelecek ölüm olayı, yine ceza normu tarafından yasaklanmış bir fiile vücut verecektir. ${ }^{47}$

3.3.2.3. Ceza Normu Tarafından Sonuç Bağlanmış İstenilmeyen İkincil Neticenin Fail Tarafindan Bilinmesi

İkinci dereceden doğrudan kastın söz konusu olabilmesi bakımından son olarak, failin davranışına bağlı olarak meydana gelecek zorunlu neticeyi bilmesi gerekir. ${ }^{48}$ Yani fail, belirli bir amaçla yaptığı davranışa bağlı olarak, ceza normunca yasaklanan ikincil bir neticenin meydana geleceğinin farkında olmalıdır ki; bu ikincil netice bakımından ikinci dereceden doğrudan kastı söz konusu olabilsin. ${ }^{49}$ Bununla birlikte bu zorunlu neticeyi bilen failin bu neticeyi amaçlamamış olması da gereklidir. Çünkü bu neticenin fail tarafından amaçlandığ 1 hallerde zaten birinci dereceden doğrudan kast söz konusu olacaktır.

46 Burada şunu vurgulamak isteriz ki, geminin açık denizde $1 \mathrm{ss} 1 \mathrm{z}$ bir yerde bulunması sonucun muhakkak ve zorunlu kabul edilmesi bakımından önemlidir. Eğer gemi limandayken batırılırsa ve failin arkadaşının çevredekiler tarafından kurtarılma ihtimali varsa veya bu kişi birkaç kulaçla karaya ulaşma imkanı bulabilecekse, bu durumda neticenin zorunluluğundan değil, ihtimal dahilinde olmasından söz edilecektir. $\mathrm{Bu}$ tür hallerde ise fail, diğer şartların da bulunmasına bağlı olarak, doğrudan kasttan değil; ancak olası kasttan sorunlu tutulabilecektir.

47 Bir suikastçı, kurbanını havaya uçuracak bombanın aynı zamanda etrafta bulunan kimseleri de öldüreceğini kesin olarak biliyorsa, her ne kadar bunu amaçlamamış olsa da, onların ölümünü istemiş sayılır. ROXIN, s.364 vd.

48 Bilinçli taksir gibi olası kastta da fail, kanunda belirtilen hususları ve davranışının tipik neticeyi meydana getirebileceğini hesaplamaktadır. WESSELS-BEULKE, s.79

49 Bilmenin yani neticenin davranışın zorunlu sonucu olmasının söz konusu olduğu hallerde doğrudan kast söz konusu olur. ROXIN, s.371 vd. 
Yukarıdaki örnek üzerinden konuyu ele almaya devam edersek; fail gemiyi batırdığı zaman yanındaki arkadaşının ölmesinin zorunlu sonuç olduğunun bilincinde olmalı, zihinsel bakımdan bu durumu tasavvur etmeli ve buna rağmen davranışını gerçekleştirmelidir (veya gerçekleştirmeye teşebbüs etmelidir).

Objektif olarak neticenin meydana gelmesi zorunlu sonuçsa; ancak fail bu durumun bilincinde değilse ve bu zorunlu sonucu sadece ihtimal dahilinde görüyorsa, bu durumda ikinci dereceden doğrudan kast sorumluluğu doğmaz. Çünkü ikinci dereceden doğrudan kast bakımından sübjektif açıdan da failin ikincil neticenin zorunlu olduğunu bilmesi gerekir. Failin objektif olarak zorunlu olan ikincil neticeyi sübjektif açıdan tam olarak tasavvur etmemesi ve bunu sadece ihtimal dahilinde kabul etmesi durumunda ise, bu ikincil neticeyi kabullenmesine bağlı olarak ancak olası kast sorunluluğu söz konusu olabilecektir. Aşağıda olası kast ile doğrudan kast arasındaki farkın ortaya konulması sirasında bu durum inceleneceğinden, burada bu genel bilgi ile yetinmeyi uygun buluyoruz.

\section{DOĞRUDAN KASTIN OLASI KASTTAN FARKI}

Doğrudan kast, gerek doktrinde kabul edilen genel görüşe gerekse TCK'nın ifadesine göre, fiilin bilerek ve istenerek işlenmesidir. ${ }^{50} \mathrm{Bu}$ tanımdan çıkan sonuçları ve bu kast türünün çeşitlerini yukarıda ayrıntılı olarak inceledik.

Olası kast ise TCK'nın 21. maddesinin 2. fikrasında, "Kişinin, suçun kanuni tanımındaki unsurların gerçekleşebileceğini öngörmesine rağmen fiili işlemesi halinde olası kast vardır." denilmek suretiyle tanımlanmıştır. ${ }^{51}$ Ancak bu tanıma bakarak olası kastın içeriğini net olarak ortaya koyabilmek ve özellikle de bilinçli taksirden ayırt etmek olukça güçtür. Çünkü bilinçli taksir halinde de fail, neticeyi öngörmesine rağmen fiili işlemektedir. Bu ikisinin arasındaki fark ise neticenin istenmemesinin net bir şekilde ortaya konulması veya kabullenilmesine bağlı olarak ortaya çıkmaktadır. Bilinçli taksir halinde, fail, öngördüğü neticenin gerçekleşmeyeceğine inandığı ve bu neticeyi istemediğini net bir şekilde ortaya koyduğu halde; olası kast durumunda ise ihtimal dahilindeki neticenin meydana geleceğini öngörmekte ve bunu kabullenmektedir. Bu bağlamda olası kast; kişinin, bir davranışına bağlı olarak

50 DEMİRASŞ, Timur. Ceza Hukuku Genel Hükümler, Seçkin Yayınevi, Ankara 2002, s.312; ÖZTÜRK-ERDEM-ÖZBEK, s.251; GROPP, s.141; BAUMANN-WEBER-MITSCH, s.471

51 Olası kast hakkında ayrıntılı bilgi için bkz. KARAKEHYA; s.19 vd. 
ortaya çıkabilecek, ihtimal dahilindeki neticenin meydana gelme tehlikesini, davranışını gerçekleştirirken kabullenmesidir. ${ }^{52}$

Olası kast kavramı bu şekilde açıklandıktan sonra doğrudan kast ile karşılaştırıldığında; özelikle ikinci dereceden doğrudan kast ile benzerlik gösterdiği fark edilmektedir. Çünkü her ikisinde de meydana gelecek netice amaçlanmamaktadır. Neticenin amaçlandığı (ve dolayısıyla istendiği) birinci dereceden doğrudan kast ile olası kastı birbirinden ayırt etmek ikinci dereceden doğrudan kasttan ayırt etmek kadar zor değildir. ${ }^{53}$ Nitekim birinci dereceden doğrudan kast her zaman amaçlanan birincil neticelere ilişkinken ve bu netice fail tarafından istenirken; olası kast her zaman için ikincil neticelere ilişkindir ve fail bu ikincil neticeleri istememekte; ancak kabullenmektedir. ${ }^{54}$

Olası kastla daha fazla benzerlik gösteren ikinci dereceden doğrudan kast ile olası kastın farkı ise, fail tarafindan tasavvur edilen ikincil neticenin zorunlu sonuç olup olmaması noktasında ortaya çıkmaktadır. Buradan da anlaşılacağı üzere gerek doğrudan gerekse olası kast ikincil neticelere ilişkin olarak ortaya çıkmaktadır. Ancak fail tarafından tasavvur edilen bu ikincil netice davranışın zorunlu sonucu ise fail ikinci dereceden doğrudan kastla hareket etmekten sorumlu olur; neticeyi istemese bile, istemiş gibi kabul edilir. $\mathrm{Bu}$ ikincil neticenin zorunlu değil de; ihtimal dahilinde bir netice olması durumunda

\section{ROXIN, s.364}

53 "Hasım telakki ettiği kişiden başka kimselerin de var olduğu lokantaya girerek önceden tanışmış olduğu Yüksel'e tevcihen tabancasını dört el ateşleyen, Yüksel'in yanı ve arka bölümlerinde bulunan kişileri de görmesi nedeniyle onlardan bir veya bir kaçının isabet alıp ölebileceğini öngörür durumda atışlarını tevali ettirerek maktul Fatih'in isabet almasına ve ölmesine neden olan sanığın, eyleminin Yüksel'i öldürmeye eksik kalkışmak ve Fatih'i gayri muayyen kasitla öldürmek olduğundan kuşku bulunmadığı...” (1. CD. 18.02.2004-3799/364) GÜNAY, Erhan, Olası Kast-Bilinçli Taksir, Öldürme ve Yaralama Kastı, Seçkin Yayınevi, Ankara 2005, s.31

54 Olas1 kastta fail neticeyi istememektedir. Onun neticeyi kabullenmesi isteme kapsamında değerlendirilemez kanaatindeyiz. Aynı yönde bkz. ÖZBEK, s.258; ancak doktrinde bunun aksi görüşler de bulunmaktadır. Bu görüşlerin temel gerekçesini ifade etmek için şu alıntıyı yapmanın uygun olacağını düşünüyoruz: “...bu kabullenme failin netice ile olan sübjektif iliş̧isini kast içinde, doğrudan doğruya kast şeklinde olmasa dahi, kurmuş olur. Artık ortada istenmemiş bir netice yoktur; diğer ifade ile istenmeyen neticenin istenmemiş olduğundan söz edilemez (nicht nicht wollen)." ÖNDER, s.273; Centel-Zafer-Çakmut ise dolaylı kastta istemenin veya istememenin açık olmadığı kanaatindedir. CENTELZAFER-ÇAKMUT s.400 
ise, fail istemediği neticeyi kabullenmiş olacak ve olası kastla hareket etmekten sorumlu tutulacaktır. ${ }^{55}$

Konuyu bir örnekle daha net açıklamak gerekirse: Failin öldürmek istediği hasmı, yanında bir arkadaşıyla motosikletle dolaşmaktadır. Fail motosiklette oturan hasmına doğru silahla ateş ettiği zaman, onun arkasında oturan hasmının arkadaşına da kurşunun isabet edebileceğini öngörmektedir. Buna rağmen ihtimal dahilinde olan bu neticeyi göze alarak silahını ateşler ve silahtan çıkan kurşun hasmını öldürdükten sonra, arkasındaki arkadaşına isabet ederek onun da ölümüne neden olursa; bu durumda fail hasmını öldürmek bakımından birinci dereceden doğrudan kast ile sorumlu olacak, hasmının arkadaşını öldürmek bakımından ise olası kast ile öldürmeden sorumlu tutulacaktır.

Buna karşın aynı kimsenin, hasmına doğru bir silahla değil de; tahrip gücü yüksek bir bomba ile saldırması sonucunda, motosikletteki her iki şahsın da ölmesi durumunda; fail hasmını öldürmekten birinci dereceden doğrudan kastla, hasmının arkadaşını öldürmekten ise ikinci derecen doğrudan kast ile sorumlu olacaktır. Nitekim atılan bombanın patlamasına bağlı olarak hasmının arkadaşının da ölmesi davranışın zorunlu sonucudur.

Daha önce de söylediğimiz üzere failin birinci veya ikinci dereceden doğrudan kast ile hareket etmesinin alacağ 1 ceza bakımından bir önemi yoktur. Sadece hakimin temel cezayı takdir ederken alt ve üst sınırlar arasında oynama yapması mümkündür. ${ }^{56}$ Buna karşın failin olası kast ile hareket ettiği durumlarda cezasında önemli bir indirim öngörülmüştür.

\section{MAĞDURUN BELİRSIZLLİĞì VE DOĞRUDAN KAST}

Bir takım suçlar bakımından, mağdurun kim olacağı, fail icra hareketlerine başladığı zaman fail tarafından bile net olarak bilinememektedir. Ancak fail, mağdurun kim olacağına önem vermeksizin, neticeyi öngörerek ve

55 Olası kast ile sorumluluk hallerinin söz konusu olabilmesi için hukuki öneme sahip olsun veya olmasın muhakkak surette failin, olası kastın ilişkin olduğu netice dışında başka bir amacının olduğundan hareketle, olası kast ile sorumluluk doğuran fiilin hep ikincil neticeye ilişkin olabileceği kanaatindeyiz. Ancak sadece hukuki öneme sahip neticeleri dikkate alan bakış açısından, olası kastın birincil neticeler bakımından da söz konusu olabileceği sonucuna varılabilir. Olası kastın birincil neticeler bakımından da söz konusu olabileceği yönünde bkz. CENTEL-ZAFER-ÇAKMUT, s.400

56 Nitekim TCK'nın 61. maddesinin 1. fikrasının (f) bendinde fail hakkında temel ceza belirlenirken, kastının ağırlığının da dikkate alınması hükme bağlanmıştır. 
isteyerek davranışını gerçekleştirir. Bu durumda gerçekleştirilen fiilin, doğrudan kast ile mi yoksa olası kast ile mi işlendiğinin tespitinde duraksama olabileceği kanaatiyle böyle bir başlık açmayı uygun gördük. Nitekim mağdurun belirsizliği neticenin ihtimal dahilinde oluşu ile karıştırılabilecektir. ${ }^{57}$

Örneğin hasmı olan büyük bir ailenin toplanma gününde, toplantının yapılacağı yere, aile adına bombalı bir paket gönderen kimsenin fiili bu tür suçlara iyi bir örnek teşkil etmektedir. $\mathrm{Bu}$ toplantı gününde fail bir hediye paketiymiş gibi kurye vasıtasıyla hasımlarının toplandığı eve bombayı gönderir. Bombayı gönderdiği zaman paketi kimin alacağı, kimin açacağına ilişkin bir fikri yoktur. Zaten fail bakımından bunun önemi de bulunmamaktadır. Onun açısından önemli olan husus o aileden birilerinin ölmesidir. Ailenin elli kişilik bir topluluk olduğu kabul edilirse bombanın elli kişiden hangisi tarafından patlatılacağı ve kimlerin öleceği fail tarafindan bilinmemektedir. Ancak fail o gruptan birilerinin ölmesini istemektedir. Yani öngördüğ̈̈ netice iradesi dahilindedir. Böyle durumlarda mağdurun belirsizliği, kastı, olası kasta çevirmez. Fiil yine doğrudan kast ile işlenmiş kabul edilir. ${ }^{58}$ Çünkü öngörülen neticenin istenmesi bir doğrudan kast türüdür. ${ }^{59}$

Bununla birlikte mağdurun belirsiz olduğu hallerde fiilin olası kast ile işlenmesi de mümkündür. Örneğin sadece gürülttü yapmak ve karışıklığa neden olmak için sakin bir parkta bomba patlatan kimsenin amacı gürültü yapmaktır. Birilerinin ölmesini ise istememektedir. Ancak her ne kadar park sakin olsa da bomba patlayacağı sırada oradan geçmekte olan birilerinin ölebileceğini öngörür

57 Bu tür haller bazı yazarlarca belirli olmayan kast ya da belirsiz kast olarak da adlandırılmaktadır. Buna göre bilinç ve iradenin, mümkün veya muhtemel fakat hangilerinin gerçekleşeceğinin şüpheli sonuçları kapsadığı hallerde, belirli olmayan kast söz konusudur. Erem-Danışman-Artuk, s.453. Belirsiz kast kavramı farklı yazarlarca farklı şekilde ele alındığı için, karışıklık doğmaması bakımından, üzerinde tam anlaşma sağlanamayan bir terimi mağdurun belirli olmamasını ifade etmek için kullanmak istemedik ve bu nedenle söz konusu durumu tam olarak ifade ettiğine inandığımız "mağdurun belirsizliğgi" terimini kullanmayı uygun bulduk. Belirsiz kastın birçok yazar tarafından farklı şekilde anlaşılması konusunda bkz. ÖNDER, s.292

58 "Kalabalığa silahla ateş eden kişi, öldürmeyi istemiș olduğuna göre, öldürülmek istenen kişinin belirsiz olması adam öldürme kastının yokluğu anlamına gelmez ve fiil taksirli değil, kasten işlenmiştir.” (CGK. 19.4.1982; 1-11/147) ÖNDER, s.274; HAKERİ, s.189

59 "Düğünü karartmak (herhangi bir kimseyi öldürerek veya yaralayarak düğünün acı bir sonla sonuçlanması), amacıyla davetlilerin bulunduğu yöne tevcih ederek iki el ateş edip ölüme neden olan sanığın fiili, kasten öldürmektir." (CGK. 19.04.1982-11/147) GÜNAY, s.63 
ve bu neticeyi kabullenir. Bu şekilde fiili gerçekleştirip birkaç kişinin ölümüne neden olan kişi bakımından olası kast ile öldürme söz konusudur. Nitekim fail ihtimal dahilindeki neticeleri öngörüp gerçekleşme riskini göze alarak (kabullenerek) fiili işlemiştir. Burada dikkat edilmesi gereken diğer bir önemli husus da; yukarıdaki örnektekine benzer şekilde, fail tarafından öngörülü kabullenilen neticenin kim üzerinde gerçekleşebileceğinin, fiilin icra hareketlerine başlandığı sırada belli olmamasıdır. Dolayısıyla bu örneklerle de ortaya koyduğumuz üzere mağdurun belirsiz olduğu hallerde fiil, doğrudan kastla işlenebileceği gibi olası kast ile de işlenebilecektir.

\section{SONUÇ}

2004 tarihli ve 5237 sayılı Türk Ceza Kanununda, suçun manevi unsur türleri bakımından dört farklı türe yer verilmiştir: (Doğrudan) Kast, Olası Kast, Bilinçli Taksir ve (Basit) Taksir. Sistematik açıdan ele alındığında ise, kanunun kast ve taksir olmak üzere iki temel tür kabul ettiği; bu iki türün de kendi içerisinde ikiye ayrıldığı görülmektedir.

Doktrinimizde suçun manevi unsuru ve kusurluluk terimleri, çoğu kez aynı içeriği ifade eden kavramlar olarak kullanılmaktadırlar. Baskın görüşe göre, kusur yeteneğine sahip fail tarafından, fiilin kasten veya kanunun öngördüğ̈̈ hallerde taksirle işlenmesi ve işlenen bu fiilde kusurluluğu kaldıran hallerden herhangi birinin bulunmaması halinde kusurluluğun (ya da manevi unsurun) varlığ kabul edilmektedir. Ancak kanaatimizce suçun manevi unsuru, fail ile fiil arasındaki psişik bağı ve bunun derecesini gösteren kalıpları ifade etmekte, bu bakımdan da kınanabilirliğe ilişkin bir kavram olan kusurluluktan farklı bir anlam içermektedir. Çünkü fail ile fiil arasındaki psişik bağ ile fiilin kınanabilirliği birbiriyle yakından ilişkili, ancak farklı hususlardır.

TCK'da doğrudan kast; suçun kanuni tanımındaki unsurların bilerek ve istenerek gerçekleştirilmesi şeklinde düzenlenmiştir. Ancak kastın unsurlarını bu şekilde bilme ve isteme olarak kabul etmektense, öngörme ve isteme olarak tespit etmek daha yerinde olacaktır kanaatindeyiz. Nitekim bilme, kelime anlamı olarak bir kesinlik ifade etmektedir. $\mathrm{Bu}$ bağlamda ancak neticenin gerçekleşeceğinin kesin olması ve failin bunu tasavvur etmesi halinde bilmeden söz edilebilir. Buna karşın doğrudan kastın söz konusu olduğu her halde, netice bakımından bir kesinliğin bulunması gerekli değildir. Dolayısıyla ihtimal dahilinde olup öngörülen (bilinen değil) neticenin istenmesi halinde de doğrudan kast söz konusu olabilecektir.

Doğrudan kastın iki temel çeşidi bulunmaktadır: Birinci derecen doğrudan kast ve ikinci dereceden doğrudan kast. Amaçlama olarak da ifade ettiğgimiz birinci dereceden doğrudan kastın öngörme ve isteme olmak üzere iki 
unsuru bulunmaktadır. Buna karşın bilme olarak ifade ettiğimiz ikinci dereceden doğrudan kast ise sadece zorunlu sonucun bilinmesinden ibarettir. Bu kast türünün varlığ 1 açısından sonucun irade edilmese de, istenmiş gibi kabul edilir. Zaten failin gerçekten neticeye ilişkin iradeye (istemeye) sahip olduğu hallerde; ikinci dereceden değil, birinci dereceden doğrudan kast söz konusu olmaktadır.

Kanunumuz doğrudan kastın çeşitleri arasında ceza miktarı bakımından bir ayrım yapmamıştır. Hatta kanundaki ifadeye bakıldığında doğrudan kastın çeşitlerinin de kanun içerisinde açıkça belirtilmediği görülmektedir. Ancak yargı içtihatları ve doktrindeki görüşler 1şığında bu tür bir ayrımı ortaya koymak, doğrudan kastın içeriğini daha iyi anlayabilmek ve cezanın bireyselleştirilmesi sırasında kastın yoğunluğunu tespit edebilmek bakımından faydalı olacaktır.

\section{KAYNAKÇA}

BAUMANN, Jürgen-Ulrich WEBER-Wolfgang MITSCH, Strafrecht Algemeiner Teil, Verlag Ernst und Werner Gieseking, Bielefeld 2003.

CENTEL, Nur-Hamide ZAFER-Özlem Yenerer ÇAKMUT, Türk Ceza Hukukuna Giriş, Beta Yayınevi, İstanbul 2005.

DEMIRBAŞ, Timur. Ceza Hukuku Genel Hükümler, Seçkin Yayınevi, Ankara 2002

DÖNMEZER, Sulhi-Sahir ERMAN, Nazari ve Tatbiki Ceza Hukuku

II, Beta Yayınları, İstanbul 1999

DRESSLER, Joshua. Cases and Materials on Criminal Law, Thomson West, St Paul MN. 2003

EREM, Faruk. Ümanist Doktrin Açısından Türk Ceza Hukuku-I, Seçkin Yayınevi, Ankara 1995

EREM, Faruk-Ahmet DANIŞMAN-Mehmet Emin ARTUK, Ceza Hukuku Genel Hükümler, Seçkin Yayınevi, Ankara 1997 Ankara 1998

GÖZLER, Kemal. Hukukun Genel Teorisine Giriş, US-A yayıncılık,

GROPP, Walter. Strafrecht Algemeiner Teil, Springer, Berlin, Heidelberg... 1998.

GÜNAY, Erhan. Olası Kast-Bilinçli Taksir, Öldürme ve Yaralama Kastı, Seçkin Yayınevi, Ankara 2005

HAKERİ, Hakan. Yeni Türk Ceza Hukukunun Temel Kavramları, Seçkin Yayınları, Ankara 2005

İÇEL, Kayıhan. Ceza Hukukunda Taksirden Doğan Subjektif Sorumluluk, İstanbul Üniversitesi Yayınları, İstanbul 1967 
İÇEL, Kayıhan-Feridun YENISEY, Karşılaştırmalı ve Uygulamalı Ceza Kanunları, Beta Yayınları, İstanbul 1994

JESCHECK, Hans-Heinrich-Thomas WEIGEND, Lehrbuch des Strafrechts Algemeiner Teil, Dunker\&Humblot, Berlin 1996

KARAKEHYA, Hakan. "Olası Kast", Ceza Hukuku Dergisi, S.2, Seçkin Yayınevi, Ankara 2006

KINDHÄUSER, Urs. Strafrecht Algemeiner Teil, Baden-Baden 2002

MITSCH, Wolfgang. "Fahrlässigkeit und Straftatsystem", Juristishe Schulung, Februar 2001

ÖNDER, Ayhan. Ceza Hukuku Genel Hükümler II-III, Beta Yayınevi, İstanbul 1992

ÖZBEK, Veli Özer. TCK İzmir Şerhi C.1, Seçkin Yayınları, Ankara 2005.

ÖZGENÇ, İzzet. Türk Ceza Kanunu Gazi Şerhi (Genel Hükümler), Seçkin Yayınevi, Ankara 2005

ÖZTÜRK, Bahri-Mustafa Ruhan ERDEM-Veli Özer ÖZBEK, Uygulamalı Ceza Hukuku ve Emniyet Tedbirleri Hukuku, Seçkin Yayınevi, Ankara 1998 1997

ROXIN, Claus. Strafrecht Algemeiner Teil-I, C.H.Beck, München

TOROSLU, Nevzat. Ceza Hukuku Genel Kısım, Ankara 2005.

WALLACE, Harvey.-Cliff ROBERSON, Principles of Criminal Law, Longman Publishers, New York 1996.

WESSELS, Johannes-Werner BEULKE, Strafrecht Algemeiner Teil, Heidelberg 2003. 